\title{
PENGARUH KITOSAN DARI CANGKANG UDANG TERHADAP RED BLOOD CELL, HEMOGLOBIN, DAN TROMBOSIT PADA MODEL RHEUMATOID ARTHRITIS YANG DIINDUKSI CFA
}

\section{THE EFFECT OF CHITOSAN FROM LOCAL SHRIMP SHELL ON RED BLOOD CELL, HEMOGLOBIN, AND TROMBOCYT IN RHEUMATOID ARTHRITIS INDUCED BY CFA MODEL}

\author{
Suyandra Sah Putra, Endang Darmawan \\ Fakultas Farmasi, Universitas Ahmad Dahlan \\ Jln. Prof. Dr. Soepomo, Janturan, Yogyakarta, Telp. (0274) 379418 \\ Email:suyandra_sahputra@ymail.com
}

\begin{abstract}
ABSTRAK
Penelitian bertujuan mempelajari efek kitosan terhadap perubahan darah tikus yang terinduksi arthtritis, dengan menggunakan metode pre-post test group control design. Penelitian terbagi dalam beberapa kelompok $(n=6)$, yaitu kelompok kontrol normal, negatif, positif, kelompok terapi kitosan dengan variasi $50 \mathrm{mg} / 200 \mathrm{gBB}$ dan $100 \mathrm{mg} / 200 \mathrm{gBB}$. Induksi arthtritis menggunakan complete freund's adjuvand (CFA) dilakukan hari pertama, selanjutnya hari ke-17 hingga 30 hari kedepan diberi perlakuan sesuai kelompoknya. Sampling darah dilakukan pada hari ke-0, 16, dan 47. Uji pemeriksaan dilakukan menggunakan metode otomatik optik dan elektronik resisten. Selanjutnya data yang diperoleh dilakukan analisis statistik menggunakan one way ANOVA $(\mathrm{p}<0,05)$. Hasil penelitian mendapatkan bahwa kitosan $50 \mathrm{mg} / 200 \mathrm{gBB}$ mampu menurunkan eritrosit sebesar $6,1 \%$ $(p<0,05)$, hemoglobin 7,77\% ( $<<0,05)$, serta PLCR 35,29\% ( $<<0,05)$, sedangkan kitosan 100 mg/200gBB mampu menurunkan trombosit sebesar 40,49\% serta PLCR 35,66\% ( $<<0,05$ ). Berdasarkan hasil penelitian dapat disimpulkan bahwa kitosan efektif memperbaiki darah tikus jantan rheumatoid arthritis dengan dosis $50 \mathrm{mg} / 200 \mathrm{gBB}$.
\end{abstract}

Kata kunci: limbah, cangkang, udang, arthritis, CFA

\begin{abstract}
The research was conducted the effect of chitosan on rats blood alteration that induced arthtritis. In addition, the research used pre-post test group control design. than used was divided into groups $(\mathrm{n}=6)$ including normal groups, positive control, negatif control, and groups were treated by khitosan at varian $50 \mathrm{mg} / 200 \mathrm{gBB}$ and $100 \mathrm{mg} / 200 \mathrm{gBB}$ doses. Adjuvant-induced was developed using complete Freund's Adjuvant on $1^{\text {st }}$ day, than $17-47^{\text {th }}$ days after treated given appropriate their groups. To evaluate did blodd counter on $0,16^{\text {th }}$, and $47^{\text {th }}$ days after treated with otomatic optic dan electronic resisten method. Than analyzed using ANOVA test and paired t-test $(\mathrm{p}<0,05)$. Result of the research is Chitosan $50 \mathrm{mg} / 200 \mathrm{gBW}$ fit to reduce of eritrocid 6,1\% (p<0,05), hemoglobin 7,77\% (p<0,05) and PLCR 35,29\% ( $<<0,05)$, meanwhile of Chitosan $100 \mathrm{mg} / 200 \mathrm{gBW}$ fit to reduce of trombocyte 40,49\% ( $>0,05)$ and PLCR 35,66\% ( $<<0,05)$. In additional research, khitosan $50 \mathrm{mg} / 200 \mathrm{gBW}$ fit to complete blood of the rheumatoid arthritic mouse well.
\end{abstract}

Keywords: eggshell, shrimp, arthritic,CFA 


\section{PENDAHULUAN}

Prevalensi penyakit arthritis di Indonesia tergolong cukup tinggi, hal ini berdasarkan hasil penelitian terakhir dari Zeng QY et al 2008, prevalensi nyeri rheumatoid arthritis di Indonesia mencapai 23,6\% hingga 31,3\%. Angka ini juga diperkuat oleh observasi yang dilakukan oleh Nainggolan (2009) yang menyimpulkan bahwa Prevalensi rematik di Indonesia adalah sebesar 32\% dengan prevalensi tertinggi berturut-turut terdapat di Provinsi Jawa Barat, Papua Barat serta Nusa Tenggara Timur dengan distribusi proporsi rematik terbesar terdapat di Provinsi Jawa Barat, Jawa Tengah dan Jawa Timur. Oleh karena itu, perlu dilakukan pengembangan obat-obat alternatif untuk penyakit arthritis, salah satunya dengan pemanfaatan bahan-bahan alam yang tersedia. The National Arthritis Action Plan: suatu Public Health Strategy (NAAP) Amerika menekankan usaha secara luas untuk mencapai kelompok populasi itu. Soet et al. (2003) menunjukkan bahwa kitosan pada tingkat seluler yaitu cytokines dapat menghambat nuclear factor $\kappa B(\mathrm{NF}-\kappa \mathrm{B})$ pada proses inflamasi. Selain itu sifat imunoprotektif dari kitosan juga mempunyai khasiat sebagai anti inflamasi pada arthtritis dengan mekanisme penghambatan pada cytokines pada sel HMC-1 (Choi et al., 2004).

Pemeriksaan darah lengkap (complete blood count/CBC) merupakan parameter yang digunakan untuk melihat adanya perubahan jenis darah antara sesudah dan sebelum perlakuan menggunakan kitin maupun kitosan yang digunakan untuk memperoleh kesimpulan dari penelitian ini. Pemeriksaan ini juga sering dilakukan untuk melihat kemajuan atau respon terapi pada pasien yang menderita suatu penyakit infeksi (Mulyanto, 2009).

\section{METODE PENELITIAN}

\section{Jenis dan Rancangan Penelitian}

Penelitian yang akan dilakukan ini merupakan jenis eksperimental dengan menggunakan rancangan pre-post test control group design.

\section{Subjek Uji}

Hewan uji yang dipergunakan adalah tikus jantan galur Sprague Dawley (SD), umur 1,5 bulan dengan berat badan 150-300 gram.

\section{Alat dan Bahan}

Alat-alat yang digunakan dalam penelitian ini yaitu peralatan gelas, seperti gelas kimia (pyrex), gelas ukur (pyrex), erlenmeyer hisap (pyrex Iwaki), batang pengaduk, corong Buchner, spatula dan pipet tetes, seperangkat alat hot-plate (Thermolyne Cimarec), spuit injection (Terumo), sonde, kertas saring, sarung tangan, neraca analitik (Adventurer) untuk menimbang sampel, thermometer air raksasa $200{ }^{\circ} \mathrm{C}$, stopwatch, blender (Cosmos), oven (Mummert), kalkulator (Casio $f x$ 350MS), stirrer, pompa vakum (Gast) untuk menyaring, alat pemeriksaan darah (Hematologi Analyzer sismex kx-21), FTIR (ABB, Swedia). Complete Freund's Adjuvant (CFA) yang mengandung Mycobacterium butyricum (Merck, London), bahan sintesis kitosan berupa $\mathrm{NaOH} 3,5 \%$ (Merck), HCL $1 \mathrm{M}$ (Merck), $\mathrm{NaOH} 50 \%$ (Merck), $\mathrm{NaOCl}$ (Brataco), aqua DM (Brataco), natrium diklofenak (Kalbe) sebagai reference drug antiradang (kontrol positif), aquadest, air bebas $\mathrm{CO}_{2}$, EDTA (Merck).

\section{Jalannya Penelitian}

Sintesis Kitosan

Kitin hasil proses deproteinasi, demineralisasi, dan depigmentasi direaksikan dengan larutan $\mathrm{NaOH} 50 \% \mathrm{~b} / \mathrm{v}$ dengan perbandingan 1:10. Campuran tersebut dengan pengaduk stirer di atas hot plate pada suhu $140{ }^{\circ} \mathrm{C}$ selama satu jam, kemudian disaring dengan menggunakan vakum hisap dan corong Buchner. Kitosan yang terbentuk dicuci dengan air hingga $\mathrm{pH}$ netral, lalu dibilas dengan aqua DM dan selanjutnya dikeringkan dalam oven pada suhu $65^{\circ} \mathrm{C}$ selama 24 jam.

Uji adjuvant-induced arthritic Pada Hewan Uji

Penelitian ini dilakukan menggunakan rancangan pre-pos test control group design. Sebanyak 42 ekor tikus galur SD jantan, dibagi menjadi beberapa kelompok $(n=6)$ dan diberi makan dan minum standar ad libitum serta perlakuan.

Tikus diinduksi dengan CFA pada hari ke-1 dan dibiarkan sampai dengan hari ke-16. Masing-masing tikus disuntik CFA pada telapak kaki kanannya sebanyak 0,1 mL (Anderson, 1970). 
Sebagai kontrol normal tikus disuntik dengan 0,1 mL larutan salin. Setelah hari ke-17 sampai dengan hari ke-47 (30 hari) tikus diberi perlakuan seperti gambar 6. Pada hari ke-17 dan ke-47 ditetapkan indeks artritis (Smit, 2000).

Pemeriksaan Darah Lengkap

Sampling darah dilakukan pada vena mata tikus bagian sinus orbitalis menggunakan pipa kapiler yang ditampung dalam eppendrof $\pm 1,5 \mathrm{cc}$ yang telah berisi EDTA untuk mecegah koagulasi (Holf, 2000). Uji pemeriksaan darah lengkap pada penelitian ini menggunakan metode otomatik optik dan elektronik resistan menggunakan alat Hematology Analyzer. Pengujian dilakukan di Lembaga Pusat Penelitian Terpadu (LPPT) Universitas Gajah Mada Yogyakarta.

\section{HASIL DAN PEMBAHASAN}

Penelitian ini dilakukan untuk mengetahui efek dari kitosan yang diberikan secara oral selama 30 hari terhadap perubahan darah lengkap dari data darah model tikus jantan galur SD terinduksi CFA.

\section{Aktivitas Antirheumatoid Arthtritis Kitin dan Kitosan}

Hasil Pemeriksaan Darah Lengkap

Parameter darah lengkap (complete blood count) sudah banyak digunakan secara luas untuk menetapkan keadaan fisiologi dan patofisiologi tubuh secara sistemik meliputi kesehatan secara umum, diagnosis, dan prognosis dari suatu penyakit (Shah et al., 2007). Komponen darah yang secara teori terjadi perubahan pada penderita rheumatoid arthritis dapat dilihat melalui gambaran darah lengkap meliputi RBC, hemoglobin, dan trombosit.

a. RBC (red blood cell)

Peningkatan jumlah RBC/eritrosit menunjukkan bahwa terjadi infeksi pada tubuh tikus. Menurut Hilmansyah (2005), terjadinya kenaikan jumlah eritrosit dimulai dari adanya infeksi, kemudian dilanjutkan dengan inflamasi. Hal tersebut menunjukkan terjadinya inflamasi pada sendi tikus. Sedangkan pada kondisi tertentu, penderita rheumatoid arthtritis mengalami anemia yang disebabkan penurunan sel darah merah (anonim, 2005).

Tabel I. Persentase perubahan eritrosit/RBC sebelum dan setelah pemberian kitosan

\begin{tabular}{|c|c|c|c|c|c|c|c|}
\hline \multirow{2}{*}{ Kelompok } & \multirow{2}{*}{$\mathrm{N}$} & \multicolumn{6}{|c|}{ Eritrosit (\%) } \\
\hline & & Hari ke 0- & $6(1$ & ata-rata \pm SE) & Hari & 17 & $47($ rata-rata \pm SE) \\
\hline kitosan $50 \mathrm{mg} / 200 \mathrm{gBB}$ & 6 & 83,24 & \pm & 66,01 & $-06,10$ & \pm & $\begin{array}{r}04,47^{\text {a) }} p=0,004 \text { b) } \\
p=0,049\end{array}$ \\
\hline kitosan $100 \mathrm{mg} / 200 \mathrm{gBB}$ & 6 & 54,51 & \pm & 15,92 & 10,50 & \pm & $04,33^{\text {b) } p=0,00}$ \\
\hline kontrol positif & 4 & 15,45 & \pm & 04,96 & $-21,22$ & \pm & 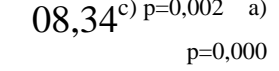 \\
\hline $\begin{array}{l}\text { Kontrol negatif } \\
\text { kontrol normal }\end{array}$ & $\begin{array}{l}6 \\
6\end{array}$ & $\begin{array}{r}-01,18 \\
13,13\end{array}$ & $\begin{array}{l} \pm \\
\pm\end{array}$ & $\begin{array}{l}04,41 \\
10,75\end{array}$ & $\begin{array}{l}14,60 \\
03,25\end{array}$ & $\begin{array}{l} \pm \\
\pm\end{array}$ & $\begin{array}{l}04,74^{\text {b) } p=0,00} \\
06,70^{\text {b) } p=0,002}\end{array}$ \\
\hline
\end{tabular}

a) Berbeda bermakna dengan kelopok kontrol negatif $(\mathrm{p}<0,05)$

b) Berbeda bermakna dengan kelompok kontrol positif $(p<0,05)$

c) Berbeda bermakna dengan kelompok kontrol normal $(\mathrm{p}<0,05)$

Data hari 0-16 terlihat terjadi kenaikan jumlah eritrosit terjadi pada semua kelompok setelah diberi induksi arthtritis berupa CFA pada hari ke-0 (Tabel I). Secara statisik dengan menggunakan uji ANOVA terjadi perbedaan bermakna antar kelompok dengan nilai $\mathrm{p}<0,05$ dan taraf kepercayaan $95 \%$.

Perubahan juga terjadi setelah semua kelompok diberi terapi selama 30 hari, kecuali kelompok normal yang tidak diberi apa-apa hanya mengalami kenaikan yang tidak begitu terlihat (Tabel I). Secara statistik perbedaan bermakna diperoleh antara kelompok kontrol negatif dengan kelompok kontrol positif natrium diklofenak. Hasil pemeriksaan eritrosit diperoleh bahwa kontrol positif dapat menurunkan sebesar $21,22 \%$ total eritrosit, dan berbeda signifikan secara statistik menggunakan uji Paired T-tes pada kelompok setelah dan sebelum perlakuan dengan nilai $\mathrm{p}<0,05$ dan taraf kepercayaan 
95\%. Sama halnya kontrol positif, kitosan dengan dosis pemberian $50 \mathrm{mg} / 200 \mathrm{gBB}$ yang diterapi selama 30 hari dapat menurunkan sebesar $6,1 \%$ total eritrosit pada tikus jantan galur SD yang terinduksi Complete Freund's Adjuvant (CFA). Namun kelompok kitosan $50 \mathrm{mg} / 200 \mathrm{gBB}$ tidak berbeda signifikan secara statistik menggunakan uji Paired T-tes pada kelompok setelah dan sebelum perlakuan dengan nilai $\mathrm{p}>0,05$ dan taraf kepercayaan $95 \%$.

a. $\quad$ PLT (Platelet/Trombosit)

Abnormalitas jumlah platelet dapat menimbulkan dua kondisi, yaitu trombositosis apabila jumlahnya melebihi normal, dan trombosit openia apabila jumlahnya kurang dari normal. Trombosistosis dapat disebabkan oleh inflamasi kronis (Skoda, 2009). Selain itu, menurut buku Pedoman Interpretasi Data Klinik yang dikeluarkan oleh Kementrian Kesehatan Republik Indonesia (2011) menjelaskan salah satu penyebab trombositosis adalah rheumatoid arthtritis.

Tabel II. Persentase perubahan trombosit/platelet sebelum dan setelah pemberian kitin dan kitosan

\begin{tabular}{|c|c|c|c|c|c|}
\hline \multirow{2}{*}{ Kelompok } & \multirow{2}{*}{$\mathrm{N}$} & \multicolumn{4}{|c|}{ Trombosit (\%) } \\
\hline & & Hari ke $0-16$ & (rata-rata $\pm \mathrm{SE})$ & Hari ke 17 & $77($ rata-rata $\pm S E)$ \\
\hline kitosan $50 \mathrm{mg} / 200 \mathrm{gBB}$ & 6 & 301,84 & $\pm 143,53$ & 45,29 & $\pm \quad 37,61$ \\
\hline kitosan $100 \mathrm{mg} / 200 \mathrm{gBB}$ & 6 & 933,43 & 141,89 & $-40,46$ & $\pm 11,98$ \\
\hline kontrol positif & 4 & 215,85 & 71,75 & $-18,14$ & $\pm \quad 09,20$ \\
\hline Kontrol negatif & 6 & 42,97 & 27,03 & 11,70 & $\pm \quad 40,91$ \\
\hline kontrol normal & 5 & 03,14 & 17,26 & $-00,82$ & $\pm \quad 28,82$ \\
\hline
\end{tabular}

Data di atas menggambarkan persentase kenaikan jumlah trombosit yang terjadi pada semua kelompok setelah 16 hari diberi induksi arthtritis berupa CFA pada hari ke-0 (Tabel II). Secara statisik dengan menggunakan uji Kruskal-Wallis (data tidak homogen) terjadi perbedaan bermakna antar kelompok dengan nilai $\mathrm{p}<0,05$ dan taraf kepercayaan $95 \%$.

Perubahan persentase hari ke 17-47 menggambarkan jumlah trombosit yang terjadi setelah semua kelompok diberi terapi selama 30 hari (Tabel II). Dari hasil uji pemeriksaan yang dilakukan diperoleh persentase penurunan trombosit pada kelompok kitosan $100 \mathrm{mg} / 200 \mathrm{gBB}$ dan kelompok kontrol positif. Namun secara statistik perbedaan tidak bermakna diperoleh antara kelompok kontrol negatif dengan kelompok kitosan $100 \mathrm{mg} / 200 \mathrm{gBB}$ dengan persentase penurunan sebesar $40,46 \%$. Penurunan juga terjadi pada kontrol positif sebesar $18,14 \%$, dan penurunan ini juga tidak berbeda bermakna dengan kelompok kontrol normal secara statistik menggunakan uji one way ANOVA dengan taraf kepercayaan 95\%, dan berbeda signifikan secara statistik menggunakan uji Paired T-tes sebelum dan setelah perlakuan.

b. Hemoglobin $(\mathrm{Hb})$

Pada kasus arthtritis, jumlah $\mathrm{Hb}$ akan semakin sedikit jika arthtritis semakin parah akibat adanya infeksi dan inflamasi pada sendi yang menyebabkan anemia, namun ini tidak selalu terjadi pada penderita rheumatoid arthtritis.

Tabel III. Persentase perubahan hemoglobin ( $\mathrm{Hb})$ sebelum dan setelah pemberian kitosan Hemoglobin (\%)

Kelompok $\quad \mathrm{N}$ Hari ke 0-16 (rata-rata \pm SE) Hari ke 17-47 (rata-rata \pm SE)

\begin{tabular}{lllllrlr}
\hline kitosan $50 \mathrm{mg} / 200 \mathrm{gBB}$ & 6 & 76,23 & \pm & 60,50 & $-07,77$ & $\pm 04,74^{\mathrm{a}) \mathrm{p}=0,002}$ \\
kitosan $100 \mathrm{mg} / 200 \mathrm{gBB}$ & 6 & 53,21 & \pm & 14,75 & 04,87 & $\pm 01,61^{\mathrm{b})=0,000}$ \\
kontrol positif & 4 & 33,97 & \pm & 09,64 & $-20,96$ & \pm & $07,31^{\mathrm{a}=0,000}$ c) \\
Kontrol negatif & 6 & 01,14 & \pm & 04,87 & 11,62 & $\pm 03,20^{\mathrm{b}) \mathrm{p}=0,000}$ \\
kontrol normal & 6 & 16,15 & \pm & 09,93 & $-00,10$ & $\pm 06,65^{\mathrm{b}) \mathrm{p}=0,003}$ \\
\hline
\end{tabular}

a) Berbeda bermakna dengan kelopok kontrol negatif $(\mathrm{p}<0,05)$

b) Berbeda bermakna dengan kelompok kontrol positif $(p<0,05)$ 
c) Berbeda bermakna dengan kelompok kontrol normal $(\mathrm{p}<0,05)$

Tanda negatif (-) menunjukkan persentase penurunan

Seperti ditunjukkan pada Tabel III bahwa pada data hari ke 0-16 menggambarkan persentase kenaikan semua kelompok terhadap jumlah total Hemoglobin, dari data ini dapat disimpulkan bahwa anemia yang menjadi komplikasi penyakit rheumatoid arthtritis tidak ditemukan. Secara statisik dengan menggunakan uji Kruskal-Wallis (data tidak homogen) terjadi perbedaan bermakna antar kelompok dengan nilai $\mathrm{p}<0,05$ dan taraf kepercayaan $95 \%$.

Pada Tabel III juga menggambarkan perubahan $\mathrm{Hb}$ yang terjadi setelah semua kelompok diberi terapi selama 30 hari. Dari hasil uji pemeriksaan yang dilakukan diperoleh penurunan yang terjadi pada kelompok kitosan $50 \mathrm{mg} / 200 \mathrm{gBB}$ dan kontrol positif sebesar 7,77\% dan 20,29\%, data diperoleh berbeda bermakna dengan kelompok kontrol negatif secara statistik menggunakan uji one way ANOVA dengan taraf kepercayaan 95\%. Namun data yang diperoleh tidak berbeda signifikan secara statistik menggunakan uji Paired T-tes pada kelompok setelah dan sebelum perlakuan dengan nilai $\mathrm{p}>0,05$ dan taraf kepercayaan $95 \%$.

c. P-LCR (Platelet Large Cell Ratio)

Perubahan P-LCR setelah diinduksi CFA sebagai induksi arthtritis mengalami peningkatan, kondisi ini sama yang terjadi pada trombosit. Menurut Mulyatno (2009) perubahan P-LCR dan trombosit terjadi pada penyakit yang sama.

Tabel IV. Persentase perubahan Platelet Large Cell Ratio (P-LCR) sebelum dan setelah pemberian kitosan

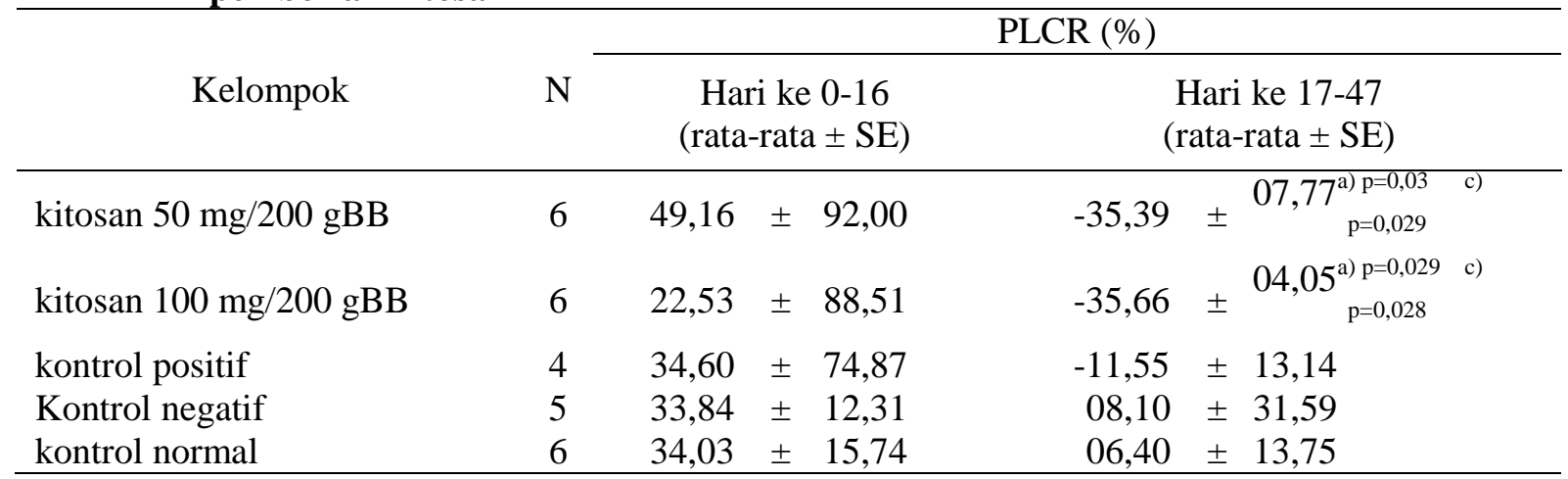

a) Berbeda bermakna dengan kelopok kontrol negatif $(\mathrm{p}<0,05)$

b) Berbeda bermakna dengan kelompok kontrol positif $(\mathrm{p}<0,05)$

c) Berbeda bermakna dengan kelompok kontrol normal $(\mathrm{p}<0,05)$

Tanda negatif (-) menunjukkan persentase penurunan

Kenaikan rasio platelet besar (P-LCR) juga terjadi pada semua kelompok setelah 16 hari diberi induksi arthtritis berupa CFA (Tabel IV). Secara statisik dengan menggunakan uji Kruskall-Wallis (data tidak homogen) terjadi perbedaan bermakna antar kelompok dengan nilai $\mathrm{p}<0,05$ dan taraf kepercayaan $95 \%$.

Penurunan yang terjadi masing-masing kelompok pada hari ke 17-47, yaitu kitosan 50 $\mathrm{mg} / 200 \mathrm{gBB}$ sebesar $35,59 \%$, kitosan $100 \mathrm{mg} / 200 \mathrm{gBB}$ sebesar $35,66 \%$, dan kontrol positif sebesar $11,55 \%$ (Tabel IV), penuruan terjdi setelah 30 hari diberi terapi. Secara statistik menggunakan uji Kruskall-wallis (data tidak homogeny) diperoleh data berbeda bermkna dengan $\mathrm{p}<0,05$ dan taraf kepercayaan 95\% dan diperoleh data berbeda signifikan secara statistik menggunakan uji Paired T-tes pada kelompok setelah dan sebelum perlakuan dengan nilai $\mathrm{p}<0,05$ dan taraf kepercayaan $95 \%$.

Kitosan mampu dijadikan sebagai antirheumatoid arthritis diperkuat oleh Penelitian yang dilakukan Utami (2015) didapat bahwa kitosan $100 \mathrm{mg} / 200 \mathrm{gBB}$ dapat menurunkan skor indeks arthtritis pada tikus yang diinduksi CFA. selain itu, pada penelitian yang dilakukan Hanifa (2015) diperoleh bahwa kitosan mampu memberikan daya anti inflamasi yang cukup efektif sebesar 142,66\% pada dosis $100 \mathrm{mg} / 200 \mathrm{gBB}$. Sedangkan, Dalam salah satu penelitian ekperimental dengan hewan uji 
ukan mujair dikatakan bahwa kitosan memiliki aktivitas untuk meningkatkan sistem imun yaitu dengan cara meningkatkan jumlah limfosit dalam sel darah putih (Hernawati et al., 2013).

\section{KESIMPULAN}

Berdasarkan penelitian pada tikus jantan SD diinduksi CFA menunjukkan bahwa pemberian oral kitosan dapat memberikan perubahan terhadap pemeriksaan darah, kitosan $50 \mathrm{mg} / 200 \mathrm{gBB}$ mampu menurunkan RBC sebesar 6,1\% ( $\mathrm{p}<0,05)$, hemoglobin sebesar 7,77\% ( $<<0,05)$, dan PLCR sebesar 35,39\% ( $\mathrm{p}<0,05)$, serta kitosan $100 \mathrm{mg} / 200 \mathrm{gBB}$ mampu menurunkan trombosit sebesar $40,29 \%$ dan PLCR sebesar 35,66\% ( $\mathrm{p}<0,05)$.

\section{DAFTAR PUSTAKA}

Anonim, 2005, Arthritis One of Three U.S. Adults Are Affected by Arthritis or Chronic Joint Symptoms, http://www.allaboutarthtritis.com/html (diakses 11 april 2014)

Hanifa, N., 2015, Pemanfaatan Limbah Cangkang Udang untuk Mengatasi Inflamasi pada Kasus Rheumatoid Arthritis pada Tikus Jantan yang Terinduksi Complete Freund'S Adjuvant(Cfa), Skripsi, Universitas Ahmad Dahlan, Yogyakarta

Hernawati, R. D., 2013, Studi Karboksimetil Kitosan terhadap Sistem Pertahanan Tubuh Non-spesifik pada Ikan Mas (Cyprinus carpio), Jurnal Sain Veteriner ISSN: 0126-0421, Universitas Gajah Mada, Yogyakarta

Hilmansyah, H., 2005, Gangguan-gangguan Autoimun Kala Hamil, Panduan Tumbuh Kembang Balita, Nakita, Di akses pada http://www.Nakita.com/kesehatan.htm diakses pada 11 april 2014

Kementrian Kesehatan Republik Indonesia, 2011, Pedoman Interpretasi Data Klinik, KEMENKES, Jakarta

Morera, D. dan MacKenzie, S. A., 2011, is there a direct role for Erytrocytes in the Imune Response?, Veterinary Reseach 10, 1-8

Mulyatno, K.C., 2009, Pemeriksaan Darah Lengkap, ITD UA, Jakarta

Nainggolan, O., 2009, Prevalensi dan Determinan Penyakit Rematik di Indonesia, Majalah Kedokteran Indonesia, vol. 59, No. 12

Skoda, R. C., 2009, Trombocytosis, Hematology: American Society of Hematology Education Program, 159-167, USA

Smit, F., 2000, Picrorhiza Scrophulariiflora from Traditional Use to Immunomodulatory, Dissertation, Rijksuniversiteit Utrech, Utrech

Utami, R. D., 2015, Aktivitas Kitin dan Kitosan terhadap Profil X-ray dan Efek Antiarthtritis Model RA yang terinduksi CFA, Skripsi, Universitas Ahmad Dahlan, Yogyakarta

Wedhowati, 2006, Pemanfaatan Jus Pisang Ambon (Musa paradisiacal sapientum. L) sebagai Neutracheutical dalam Memperbaiki Sel Sinovial Tikus Jantan Arthtritis yang Terinduksi CFA, Skripsi, Universitas Islam Indonesia, Yogyakarta

Zeng, Q.Y. 2008. Effect of tumor necrosis factor a on disease arthritis reumatoid. Journal of Experimental Medicine, 180: 995-1004 